\title{
ENERGY EXPENDITURE OF SWIMMERS AND SCUBA DIVERS
}

Przemysław Michniewski

Department of Maritime and Tropical Medicine, Military Medical Institute, Gdynia, Poland

\section{ABSTRACT}

This article discusses the energy input and effort of swimmers during long-distance swimming, classifying them according to the definitions of work intensity. It also refers to the diver's effort while performing tasks underwater

Keywords: effort, swimming, scuba diver, energy value.

\section{ARTICLE INFO}

PolHypRes 2019 Vol. 69 Issue 4 pp. 91 - 96

ISSN: $1734-7009$ elSSN: 2084-0535

DOI: $10.2478 / \mathrm{phr}-2019-0023$

Pages: 6, figures: 0 , tables: 5

Review article

page www of the periodical: www.phr.net.pl

Article from 1974, unpublished

Publisher

Acceptance for print in PHR: 17.03.2018 r.

Polish Hyperbaric Medicine and Technology Society 


\section{INTRODUCTION}

Most authors analysing the burden of work and physical effort in various occupations and sports classify swimming and diving as heavy or very heavy work $[1,2,5,6,7,8,9]$. One of the elements of the assessment of the workload is to determine the amount of energy expenditure, expressed as the amount of calorie consumption in connection with work performed $[3,4]$.

In the body of a person doing physical work, considerable amounts of heat are generated, just like in a running combustion engine. The energy source of the engine is fuel in the form of petrol or diesel oil, while the energy source for working muscles is the "burning" of carbohydrates, fats and proteins contained in food. The energy released as a result of chemical changes in the body is expressed in units of thermal energy, i.e. in calories or kilocalories (cal, kcal). During the burning of $1 \mathrm{~g}$ of carbohydrates into carbon dioxide and water, $4.1 \mathrm{kcal}$ are produced (similarly to $1 \mathrm{~g}$ of protein) and of $1 \mathrm{~g}$ of fats - 9.3 kcal. Each form of energy can be transformed into other forms, e.g. chemical into mechanical and the latter into thermal, so when considering the amount of energy spent, different units of work, energy and power can be used. For example:
$1 \mathrm{cal}=4.186$ joules

1 kilocalory $(\mathrm{kcal})=1000 \mathrm{cal} \mathrm{kcal} / \mathrm{h}=1.163 \mathrm{~W}$

1 watt $(\mathrm{W})=$ joule $/ \mathrm{s}=2.389 \times 10^{-1} \mathrm{cal} / \mathrm{s}$

$1 \mathrm{kGm} / \mathrm{min}=2.34 \times 10^{-3} \mathrm{kcal} / \mathrm{min}=2.19 \times 10^{-4} \mathrm{KM} / \mathrm{min}$

$1 \mathrm{KM} / \mathrm{min}=1.07 \times 10 \mathrm{kcal} / \mathrm{min}$

A 1 kilowatt bulb, for example, produces heat in the amount of $14.4 \mathrm{kcal} / \mathrm{min}$, which corresponds to the amount of heat produced by 10 adult people who are sitting and busy talking [1]. In physiology, the energy value of food is expressed in kcal. A person at rest uses the energy corresponding to $1 \mathrm{kcal} / \mathrm{min}$. As a source of energy, the human body is an inefficient instrument. Its power per kilogram of body weight is $0.005-0.007 \mathrm{HP} / 1 \mathrm{HP}=735.5$ $\mathrm{W}$. The same size for a combustion engine is $1.4 \mathrm{hp} \mathrm{x} \mathrm{kg-1}^{-1}$. The body's efficiency, understood as the ratio of useful energy to total energy consumed, is $20 \%$, which means that for each kilocalorie spent in the form of work there are $4 \mathrm{kcal}$ spent as heat [4]. The efficiency of the steam engine is $25 \%$ and that of the combustion engine $30-40 \%$.

The attached Table I provides data on the energy obtained from the oxidation of nutrients as well as on the $\mathrm{RQ}$ ratio, i.e. the ratio of carbon dioxide produced by the organism to oxygen absorbed.

\begin{tabular}{llllll}
\hline Energy obtained by oxidation of nutrients [1]. & $\begin{array}{l}\text { Required } \\
\text { quantity of } \mathrm{O}_{2} \\
\text { per } \mathrm{ml}\end{array}$ & $\begin{array}{l}\text { Quantity of } \\
\text { produced } \mathrm{CO}_{2} \text { per } \\
\text { ml }\end{array}$ & $\mathrm{RQ}$ & Energy kcal & $\begin{array}{l}\text { Calorific } \\
\text { equivalent of } \\
\text { oxygen }\end{array}$ \\
\hline Starch & 828,8 & 828,8 & 1,000 & 4,183 & 5,047 \\
\hline Animal fat & 2019,2 & 1427,3 & 0,707 & 9,461 & 4,686 \\
\hline Protein & 966,1 & 782,7 & 0,809 & 4,442 & 5,600 \\
\hline
\end{tabular}

The overall energy expenditure of the body consists of three components:

- Basal metabolic rate (BMR) defined for a person during physical and mental rest. BMR is about $1 \mathrm{kcal} / \mathrm{h} / \mathrm{kg}$ body weight. For example, in a man weighing $70 \mathrm{~kg} \mathrm{BMR}=1680 \mathrm{kcal} / 24 \mathrm{~h}$.

- Functional metabolism (washing, shaving, eating, etc.). This form of metabolism amounts on average to $400 \mathrm{kcal}$ for men and $300 \mathrm{kcal} / 24 \mathrm{~h}$ for women.

- Working metabolism (working energy expenditure) closely related to work or sport (swimming, diving) and usually expressed in $\mathrm{kcal} / \mathrm{min}$.

In practice, the so-called indirect calorimetry method is used to measure the working output of energy, consisting of measuring the volume of exhaled air and chemical analysis of its composition $\left(\mathrm{O}_{2}, \mathrm{CO}_{2}\right)$. If the respiratory quotient $\mathrm{RQ}$ is, for example, 0.85 , then 1 litre of oxygen consumed corresponds to the production of 4.85 kcal of energy. By multiplying the amount of oxygen consumed in litres by 4.85 , the amount of energy released can be calculated. Industrial physicians use the readymade data in the tables and expressed in $\mathrm{kcal} / \mathrm{min}$ for various professional activities and sports. The SpitzerHettinger energy expenditure tables are in common use [8].
Tables II, III, IV and V below present, for illustration purposes, data defining energy expenditure in the course of particular types of work, data on swimmers crossing the English Channel, energy expenditure and oxygen consumption by divers and scuba divers, and finally energy expenditure depending on style and speed of swimming. 
Classification of work in industry [1].

\begin{tabular}{lll}
\hline \multirow{2}{*}{ Work } & Energy expenditure & \\
\cline { 2 - 3 } & Men kcal/min/65 kg & Women $\mathrm{kcal} / \mathrm{min} / 55 \mathrm{~kg}$ \\
\hline Light & $2.0-4.9$ & $1.5-3.4$ \\
\hline Medium heavy & $5.0-7.4$ & $3.5-5.4$ \\
\hline Heavy & $7.5-9.9$ & $5.5-7.4$ \\
\hline Very heavy & $10.0-12.4$ & $7.5-9.4$ \\
\hline Extremely heavy & $12.5-\ldots$ & $9.5-\ldots$ \\
\hline
\end{tabular}

Contestants, participants in the English channel swimming competition (1955 r.).

\begin{tabular}{|c|c|c|c|c|c|c|c|c|c|c|}
\hline $\begin{array}{l}\text { Contest } \\
\text { ants }\end{array}$ & $\begin{array}{l}\text { Age in } \\
\text { years }\end{array}$ & $\begin{array}{l}\text { Height } \\
\text { in } \mathrm{cm}\end{array}$ & $\begin{array}{l}\text { Weight } \\
\text { in kg }\end{array}$ & $\begin{array}{l}\text { Body } \\
\text { surface } \\
\text { in } \mathrm{m}^{2}\end{array}$ & $\begin{array}{l}\text { Speed } \\
\mathrm{km} / \mathrm{h}\end{array}$ & $\begin{array}{l}\text { Moves } \\
\text { per } \\
\text { minute }\end{array}$ & $\begin{array}{l}\text { Lung } \\
\text { venti- } \\
\text { lation } \\
1 / \mathrm{min}\end{array}$ & $\begin{array}{l}\mathrm{O}_{2} \\
\text { consum- } \\
\text { ption } \\
1 / \mathrm{min}\end{array}$ & $\begin{array}{l}\text { Energy } \\
\text { expen- } \\
\text { diture } \\
\text { kcal/mi } \\
\text { n } \\
\end{array}$ & $\begin{array}{l}\text { Vital } \\
\text { capa- } \\
\text { city of } \\
\text { lungs } 1\end{array}$ \\
\hline \multicolumn{11}{|l|}{ Men } \\
\hline 1.N.B. & 58 & 164.0 & 91.2 & 1.98 & 2.65 & 42.4 & 58.3 & 2.39 & 11.7 & 4.2 \\
\hline 2.G.G. & 25 & 172.0 & 82.3 & 1.96 & 3.22 & 50.4 & 54.6 & 3.10 & 15.0 & 5.8 \\
\hline 3.B.P. & 34 & (B)160.2 & 76.5 & 1.80 & 3.43 & 58.2 & 65.4 & 3.09 & 14.4 & 3.3 \\
\hline 4.M.S & 25 & 157.8 & 63.0 & 1.62 & 3.65 & 66.9 & 61.4 & 2.37 & 11.6 & 3.2 \\
\hline
\end{tabular}

Width of English Channel $34.5 \mathrm{~km}$ Acc. to Pugh et al. $[6,7]$

Time of swimming $12-17 \mathrm{~h}$.

Assuming an average swimming time over the above distance of $14 \mathrm{~h}$, the energy expenditure of the competitors will be between 10,000 and 13,000 kcal.
On 6.08.1970 Kevin Murphy crossed the English Channel back and forth in $35 \mathrm{~h} 10$ minutes.

The energy expenditure connected with covering almost $70 \mathrm{~km}$ of the route is estimated at $17-21,000 \mathrm{kcal}$.

Energy expenditure and oxygen consumption by divers and scuba divers [1].

\begin{tabular}{lllll}
\hline $\begin{array}{l}\text { Experimental } \\
\text { conditions }\end{array}$ & $\begin{array}{l}\text { Average oxygen } \\
\text { consumption } \\
1 / \mathrm{min}\end{array}$ & & $\begin{array}{l}\text { Average } \\
\text { expenditure kcal/min }\end{array}$ & $\begin{array}{c}\text { energy } \\
\text { Diving in a swimming } \\
\text { pool with equipment } \\
\text { and a suit }\end{array}$ \\
\hline Sitting, standing & 0.26 & $0.20-0.32$ & 1.3 & \\
\hline Minimum movement & 0.57 & $0.40-0.73$ & 2.9 & $1.0-1.6$ \\
\hline Maximum movement & 1.53 & $1.24-1.96$ & 7.7 & $6.2-9.8$ \\
\hline Diving in open waters & & & $3.8-8.1$ \\
\hline Minimum movement & 1.08 & $0.75-1.61$ & 5.4 & \\
\hline Maximum movement & 1.96 & $1.41-2.35$ & 9.8 & \\
\hline $\begin{array}{l}\text { Underwater swimming } \\
\text { in a pool, flippers, }\end{array}$ & & & & \\
without a suit & & & 11.8 \\
\hline Moderate movement & 2.32 & $1.60-2.68$ & 11.6 & $13.3-18.8$ \\
\hline Considerable mobility & 3.09 & $2.65-3.60$ & 15.5 & \\
\hline
\end{tabular}


Energy expenditure in the function of swimming style and speed.

\begin{tabular}{llll}
\hline \multirow{2}{*}{ Style } & Speed & & $\begin{array}{l}\text { Energy expenditure } \\
\text { Kcal/h/70 kg }\end{array}$ \\
\cline { 2 - 4 } & $\mathrm{Km} / \mathrm{h}$ & $\mathrm{m} / \mathrm{min}$ & 410 \\
\hline Classic & 1.85 & 30.8 & 420 \\
\hline Freestyle (Crawl) & 1.85 & 30.8 & 500 \\
\hline On the back & 1.85 & 30.8 & 700 \\
\hline Freestyle (Crawl) & 2.96 & 49.3 & 1600 \\
\hline Freestyle (Crawl) & 4.07 & 67.9 & 1850 \\
\hline Classic & 4.07 & 67.9 & 2530 \\
\hline Classic & 4.44 & 74.0 & 3690 \\
\hline Classic & 4.99 & 83.2 & \\
\hline
\end{tabular}

Comparison of the data contained in Tables I-V allows for a correct assessment of the physical effort of swimmers and scuba divers, which is of great importance in the process of their training.

Knowing the energy expenditure per minute allows for objective assessment of the physical burden of the working system and operation using generally known units such as "cal", "kcal", "kcal/min". Nowadays, when most of the work has been mechanised, the working energy expenditure is in the range of 500-3000 kcal/day and will probably decrease due to further technological progress. The situation is different in sports. It is observed from year to year and from one Olympics to another that the existing records associated with long-term physical effort such as swimming, marathon running, cycling marathons, cross-country skiing etc. are constantly being broken. Achieving by swimmers within a dozen or so hours of energy expenditure of $12-17000 \mathrm{kcal}$ or even more, shows the existence of hitherto unknown possibilities of energy expenditure by the human organism.

Work with an energy output of more than 10 $\mathrm{kcal} / \mathrm{min}$, described as very heavy according to the data from Table No. II, is performed by the manual worker in the course of their normal working day over short periods of time. The load on a long-distance swimmer with an energy output of $15 \mathrm{kcal} / \mathrm{min}$ lasts several hours without interruption. Unlike a combustion engine, a human being can work without fuel (food), burning his or her own energy resources in the form of glycogen and adipose tissue, naturally over a limited time. However, a healthy and fully functioning body requires a constant supply of food, equivalent to the calorific value of the energy spent.

What should be the daily calorific demand of a swimmer at an energy output of e.g. $12000 \mathrm{kcal} /$ day?

Daily quantity of calories in food = working energy expenditure+functional energy expenditure+BMR kcal

A value of 0.88 in the denominator indicates that only $88 \%$ of the consumed food is assimilated and can provide energy.

Daily calorific demand of a swimmer $=$ $\frac{12000+400+1700}{0,88} \mathrm{kcal}=16022 \mathrm{kcal}$.

In the extremely hard-working body of a swimmer, the universally applicable law on energy conservation has been violated. The energy expenditure has far exceeded the supply, because despite taking food while swimming, it is impossible to assimilate in the same time $16,000 \mathrm{kcal}$ (1.8 $\mathrm{kg}$ fat or more than $4 \mathrm{~kg}$ protein in meat). The energy balance of such a highly stressed body is balanced out in a few or more days. Hence the conclusion that a repetition of such an effort can take place after a sufficiently long break.

\section{ConCluSions}

- Determination of energy expenditure in commonly known physical units such as cal, kcal, $\mathrm{kcal} / \mathrm{min}$ allows for objective, comparative assessment of physical effort in professional work, military service and sports.

- The physical effort of swimmers and scuba divers, assessed on the basis of their energy expenditure, is considered to constitute heavy and extremely heavy work.

- The knowledge of the energy expenditure ranges for different jobs and activities allows military commanders and coaches in sport to efficiently gauge the effort of competitors.

- The knowledge of energy expenditure per minute makes it possible to compare the physical effort of a swimmer, runner or mountaineer and to estimate their calorific demand. 


\section{REFERENCES}

Durnin J., Passmore R.: Energy, work and leisure. PWN, Warsaw 1969;

Falls H.: Exercise physiology. Acad. Press, N. York 1968;

Kozłowski S.: Physical effort physiology. PZWL, Warsaw 1970;

Krause M.: An overview of ergonomics. PZWL, Warszawa 1970

Michniewski P.: Lekarz Wojsk. 1971, 6; 554

Morehouse L., Miller A.: Physiology of exercise. Mosby Co, S. Louis 1967;

Pugh L. et al.: Clin. Sci. 1960, 19; 257;

Pugh L., Edholm O.: Lancet, 1955, 8; 733 .

Spitzer-Hettinger: Tafeln fur den Kalorienumsatz bei korperlicher Arbeit. Beuth Vertrieb GmBH, Berlin 1964. 